\title{
Chondroma of the Cerebral Falx: Case Report of a Very Rare Intracranial Tumor
}

\section{Condroma da foice do cérebro: relato de caso de um tumor intracraniano muito raro}

\author{
Eduardo Procaci da Cunha ${ }^{1}$ José Eduardo Alves ${ }^{1}$ Ricardo Taipa ${ }^{1} \quad$ Joaquim Reis ${ }^{1}$ Manuel Melo Pires ${ }^{1}$ \\ Rui Rangel ${ }^{1}$ \\ ${ }^{1}$ Department of Neurosurgery, Centro Hospitalar do Porto, Hospital \\ de Santo António, Porto, Portugal \\ Arq Bras Neurocir 2015;34:144-147. \\ Address for correspondence Eduardo Procaci da Cunha, MD, \\ Departamento de Neurocirurgia, Centro Hospitalar do Porto, Largo \\ Prof. Abel Salazar, Oporto, Portugal CEP 4099-001 \\ (e-mail: eduardopcunha@gmail.com).
}

\begin{abstract}
Keywords

- chondroma

- intracranial

- falx

- meningeal

- tumor

- dura

Resumo

\section{Palavras-chave}

- condroma

- intracraniano

- foice

- meníngea

- tumor

- dura-máter

Chondromas are a benign cartilaginous tumor that account for approximately $0.5 \%$ of primary intracranial tumors. They usually arise from the synchondrosis of the skull base, being rarely reported elsewhere (dura convexity, falx, or even intraparenchymal). Because they are very rare tumors sharing clinical behavior and imagiological similarities with the much more common meningioma, the clinical diagnosis is frequently mistaken after an initial imaging workup. The authors present a case of a 48-year-old woman, with frequent headaches and an extra-axial tumor arising from the anterior falx, initially diagnosed as a meningioma.

Condromas são tumores cartilaginosos benignos que correspondem por aproximadamente $0,5 \%$ dos tumores primários intracranianos. Eles geralmente surgem da sincondrose da base do crânio, sendo raramente registrados em outros locais como a convexidade dural, a foice, até mesmo no parênquima cerebral. Por serem tumores muito raros que compartilham comportamento clínico e imagiológico com meningiomas, o diagnóstico é frequentemente confundido após exame de imagem inicial. Os autores apresentam o caso de uma mulher de 48 anos, com cefaleia frequente e um tumor extra-axial ascendendo da foice anterior, inicialmente diagnosticado como um meningioma.
\end{abstract}

\section{Introduction}

Chondroma is a benign cartilaginous tumor, usually arising from the small bones of hands and feet, but also been found on several sites of the body. ${ }^{1,2}$ They are rarely diagnosed inside the cranial vault, and in that case more frequently related with the skull base. Nevertheless, there are few isolated cases reports of chondromas arising from the con- vexity dura, falx, choroid plexus, or intraparenchymal. ${ }^{3-5}$ Because they are very rare intracranial tumors with a slow growing pattern and share imagiological similarities with meningiomas, they can be frequently mistaken, especially when are located outside the skull base.

Therefore, we present a case repot of a 48-year-old woman, with a history of frontal headaches and an extraaxial mass arising from the anterior falx. Initially this tumor received

January 13, 2014

accepted

March 31, 2015
DOI http://dx.doi.org/

$10.1055 / \mathrm{s}-0035-1554739$.

ISSN $0103-5355$.
Copyright $\odot 2015$ by Thieme Publicações License terms Ltda, Rio de Janeiro, Brazil
(1) $\Theta \circledast$ 


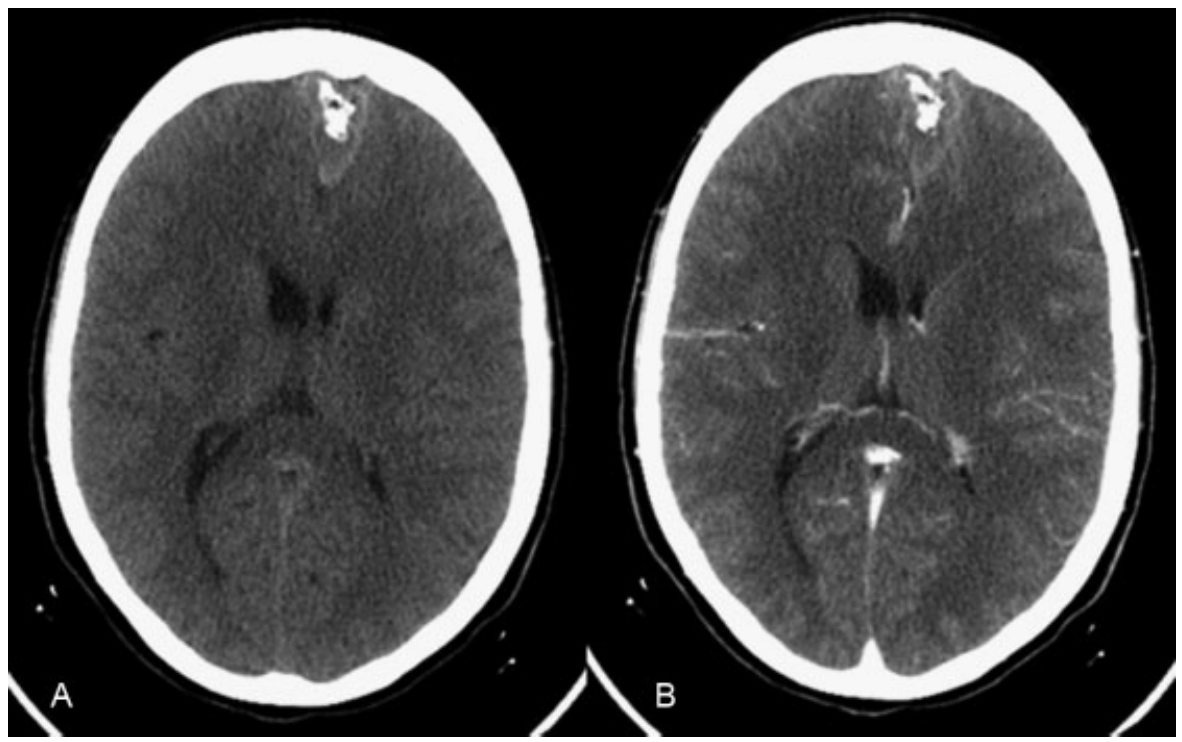

Fig. 1 Axial computed tomographic (CT) scan before (A) and after (B) contrast injection showing an extra-axial interhemispheric mass, implanted on the falx cerebri. It presents a hypodense central core and a hyperdense peripheral rim, multiple coarse calcifications, and no obvious enhancement.

was considered a meningioma. After surgery the histology revealed a falx chondroma.

\section{Case Report}

We present a case of a 48-year-old woman with a long history of frontal headache, and an initially good response with analgesics. She was studied with a computed tomography (CT) scan after a period of more frequent and intense episodes of headache.

The computed tomographic (CT) scan revealed a sharply demarcated, extra-axial, interhemispheric mass, implanted on the falx cerebri, measuring $55 \times 26 \times 25 \mathrm{~mm}$. It was predominately hypodense with a hyperdense peripheral rim, presented multiple coarse calcifications and had no obvious enhancement after contrast (-Fig. 1).

On magnetic resonance imaging (MRI), the tumor showed T1 and T2 heterogeneous signal, with a peripheral component similar to the cortex and a hyperintense central core, with foci of low $\mathrm{T} 2 / \mathrm{T}^{*}$ signal due to calcifications. After gadolinium, there was slight, nonhomogenous enhancement, mainly at its periphery. The surrounding parenchyma was molded but without signs of peritumoral vasogenic edema (-Fig. 2 ).

Based on neuroimaging, the initial diagnosis was of a meningioma, and after careful explanation of the prognosis, the patient preferred a conservative approach. She underwent 6-month interval checkup evaluations and yearly MRIs. Four years after the initial scan, the magnetic resonance imaging (MRI) showed a small increase in lesion's overall dimensions and surgical treatment was proposed.
During the surgery, we could observe that the tumor was a white firm mass, easily dissected from the cortex, without hemorrhage during progressive piece-meal resection, and ultimately inserted on the right lateral wall of superior sagittal sinus. Histologic examination showed a tumor primarily composed of lobules of hyaline cartilage with mild nuclear atypia and rare binuclear forms; however, no mitotic figures were seen (-Fig. $\mathbf{3}$ ). There was no immunoreactivity for Ki-67. The diagnosis was of a chondroma. Tumor removal was complete.

\section{Discussion}

Intracranial chondroma is a very rare differential diagnosis of a falx implanted tumor, since it accounts for less than $0.5 \%$ of primary intracranial tumors. ${ }^{6}$ They are usually solitaireexcept when associated with Maffucci syndrome or Ollier multiple enchondromatosis ${ }^{7-9}$-and commonly located at the skull base. There are few cases reports elsewhere in the cranial vault, like the convexity dura, falx, choroid plexus or even within the brain parenchyma. ${ }^{3-5}$ In fact, fewer than 30 falcine chondromas have been reported in the literature. $^{10}$

Because of its slow growth pattern, the tumor can reach considerable size before eliciting any symptoms, delaying the diagnosis. The clinical manifestations are nonspecific and depend mainly on its size and location. Thus, it can be a neurologic deficit, psychologic, or personality change, or even intracranial hypertension as any other slow growing. $1,5,11,12$

Its origin is yet a matter of debate, with some studies mentioning an origin from meningeal fibroblasts metaplasia, 


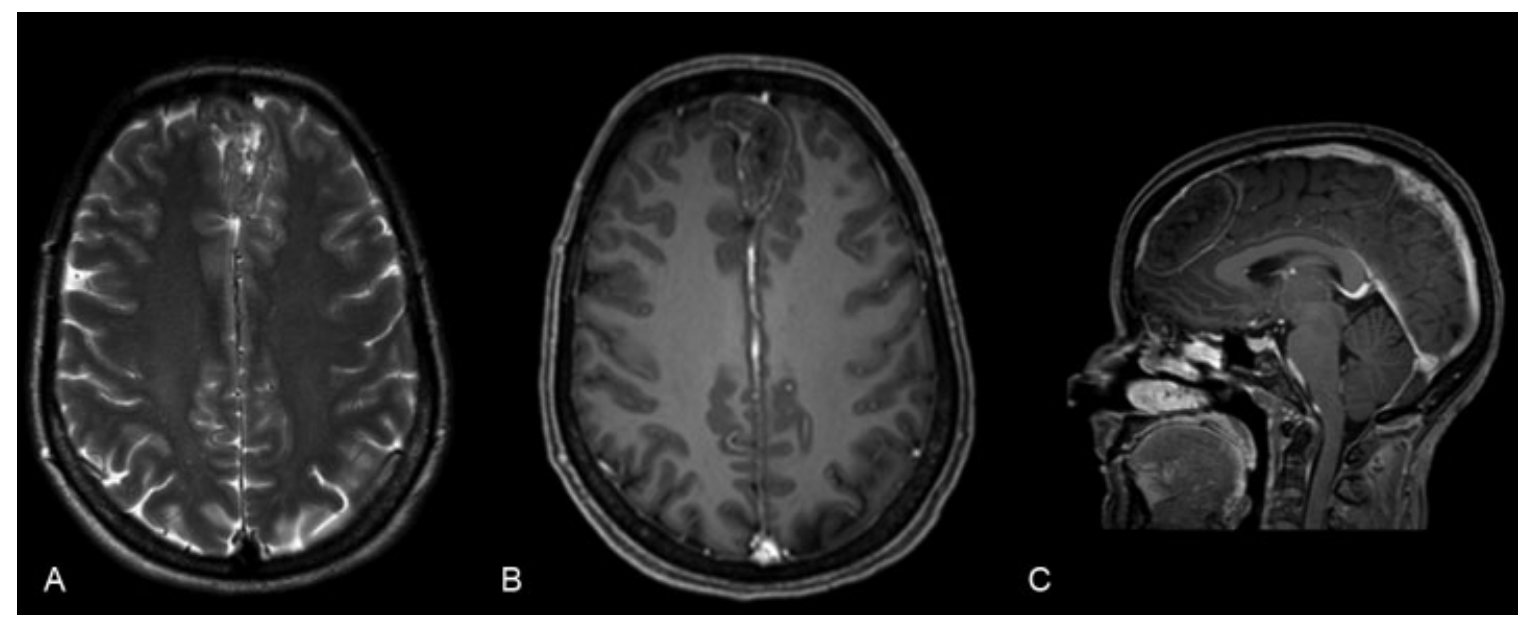

Fig. 2 Axial T2 SE (A) slice reveals a very heterogeneous mass, with peripheral signal identical to the cortex and a hyperintense central core with foci of low signal within it. After gadolinium (B, C), the lesion presents slight nonhomogenous enhancement mainly at its periphery.
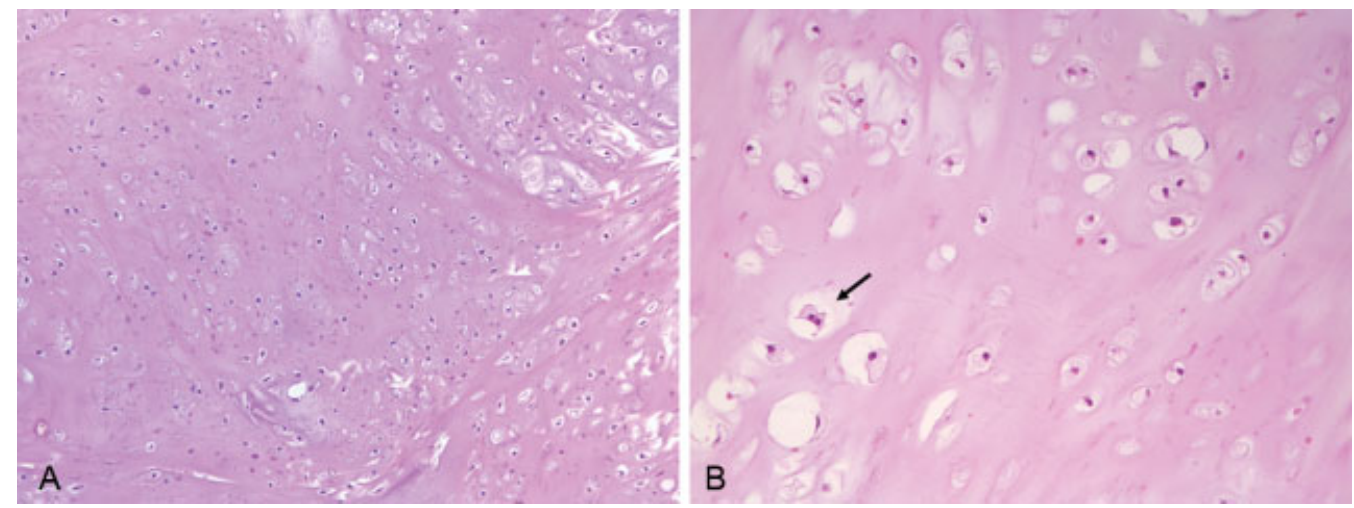

Fig. 3 (A, B) Microscopic examination showed a tumor primarily composed of lobules of hyaline cartilage with mild nuclear atypia and rare binuclear forms (black arrow); however, no mitotic figures were seen.

others claiming that the tumor may arise from multipotential or perivascular mesenchymal cells or still, from aberrant nests of cartilage forming cells in the dura. ${ }^{4,13-15}$ There are cases reports of patient age ranging from 15 months to 60 years, with a peak at the third decade. ${ }^{3}$

When found outside the skull base, the diagnosis is even more challenging. The main reasons being imagiological and clinical similarities with the much more common meningioma, and of course its rarity. Although in most cases the chondroma will follow a benign course, there is a report of intratumoral and subarachnoid hemorrhage associated with a clival chondroma. ${ }^{16}$ Although Maheshwari et al previously mentioned a relationship between Maffucci syndrome and a malignant transformation of a chondroma, ${ }^{17}$ we could not find this association in the referred article. ${ }^{18}$ Actually van Nielen and de Jong mentioned a malignant transformation of a low-grade glioma in a patient with Maffucci syndrome.

The imaging characteristics of convexity and falcine chondromas are nonspecific. On CT, the tumor appears as a wellcircumscribed extra-axial mass with calcifications in at least $60 \%$ of cases. ${ }^{19-21}$ Like in all chondromas, these calcifications are usually multifocal, curvilinear, and irregular, with a coarse aspect. In 50 to $60 \%$ of the cases, the convexity-based lesions may induce either hyperostosis or scalloping of the adjacent calvarium. ${ }^{21}$ The tumor may be homogeneously iso-, hyper-, or hypodense or it can have a more heterogeneous presentation, with a central hypodense area that constitutes a degenerative cyst. ${ }^{22,23}$ After contrast injection, early enhancement is typically minimal, although mild to moderate delayed enhancement has been reported. ${ }^{24-26}$

On MRI, they show heterogeneous signal, due to the association of a cartilaginous matrix (characteristically hyperintense on $\mathrm{T} 2$ and hypointense on T1) with multiple calcifications (usually hypointense on $\mathrm{T} 2 / \mathrm{T}^{*}$ and hyperintense on T1). After gadolinium these lesions present slight, heterogeneous enhancement, mainly at the periphery. Like all benign mesenchymal tumors, convexity and falcine chondromas do not incite dural reactions, so a "dural tail" sign is absent. $^{15,19,26}$

As in our case, the main misleading diagnosis is meningioma, by far the most common intracranial extra-axial tumor, which also presents with calcification. The neuroimaging differentiation of these two entities is not always easy but the lack of homogeneous enhancement, the nonvascular appearance and the absence of a dural tail should point to other diagnosis than meningioma. Histologically the 
differential diagnosis would be a meningioma with extensive chondroid metaplasia, but in this case there were no areas of nonchondroid elements that could be recognized.

Another important distinction is with chondrosarcoma, the malignant version of chondroma. Chondrosarcomas are tumors of young adults (fourth and fifth decades) and slight male predominance. ${ }^{27}$ On neuroimaging they present as aggressive looking extra-axial masses, with signs of necrosis and hemorrhage, bone destruction, and frequent brain invasion. ${ }^{28}$ Unlike chondromas, they usually demonstrate heterogeneous but intense contrast-enhancement. Although the differential diagnosis between chondrosarcoma and benign chondromas can be difficult on a histologic basis, in the histologic evaluation of our case there was no sufficient evidence of anaplasia to consider the lesion as chondrosarcoma

The intracranial chondromas usually follow a benign course with a slow growth rate and favorable prognosis. When indicated, surgical removal of the tumor with its dural attachment is the treatment of choice. Partial removal can be considered for neural decompression when there is high risk of eloquent structures damage with a more aggressive approach. Because chondromas are radioresistant, radiation therapy is not indicated in any case scenario. $^{27,28}$ After total removal recurrence is not expected.

\section{Conclusion}

Chondromas can rarely arise from the falx cerebri and are frequently misdiagnosed as a meningioma. Although the CT and MRI appearance is not pathognomonic, some features can suggest this type of tumor. The tumor follows a benign course, and when indicated surgery is the treatment of choice with no recurrence expected after total removal. Pathologic distinction from chondrosarcoma should be done in all cases as prognosis and subsequent treatment differs.

\section{References}

1 Colpan E, Attar A, Erekul S, Arasil E. Convexity dural chondroma: a case report and review of the literature. J Clin Neurosci 2003; 10(1):106-108

2 Atalay FO, Ozgun G, Tolunay S, Bekar A. Intracranial extra-axial chondroma: a case report. J Nippon Med Sch 2014;81(1):35-39

3 Fountas KN, Stamatiou S, Barbanis S, Kourtopoulos H. Intracranial falx chondroma: literature review and a case report. Clin Neurol Neurosurg 2008;110(1):8-13

4 Erdogan S, Zorludemir S, Erman T, et al. Chondromas of the falx cerebri and dural convexity: report of two cases and review of the literature. J Neurooncol 2006;80(1):21-25

5 Zhan RY, Pan XF, Wan S, et al. Solitary intracerebral chondroma without meningeal attachment: a case report with review of the literature. J Int Med Res 2011;39(2):675-681

6 Doran SE, Gebarski SS, Hoff JT. Tumors of the skull. In: Youmans JR, ed. Neurological Surgery, vol. 4. Philadelphia, PA: WB Saunders Publishers; 1996:3003
7 Chakrabortty S, Tamaki N, Kondoh T, Kojima N, Kamikawa H, Matsumoto S. Maffucci's syndrome associated with intracranial enchondroma and aneurysm: case report. Surg Neurol 1991; 36(3):216-220

8 Traflet RF, Babaria AR, Barolat G, Doan HT, Gonzalez C, Mishkin MM. Intracranial chondroma in a patient with Ollier's disease. Case report. J Neurosurg 1989;70(2):274-276

9 Ghogawala Z, Moore M, Strand R, Kupsky WJ, Scott RM. Clival chondroma in a child with Ollier's disease. Case report. Pediatr Neurosurg 1991-1992/1992;17(1):53-56

10 Abbasi A, Azmoudeh Ardalan F, Miri SM, Shahriarian S, Tajik F. Chondroma of falx: case report of a rare condition. Acta Med Iran 2012;50(3):222-224

11 Brownlee RD, Sevick RJ, Rewcastle NB, Tranmer BI. Intracranial chondroma. AJNR Am J Neuroradiol 1997;18(5):889-893

12 Sarwar M, Swischuk LE, Schecter MM. Intracranial chondromas. AJR Am J Roentgenol 1976;127(6):973-977

13 Kurt E, Beute GN, Sluzewski M, van Rooij WJ, Teepen JL. Giant chondroma of the falx. Case report and review of the literature. J Neurosurg 1996;85(6):1161-1164

14 Dutton J. Intracranial solitary chondroma. Case report. J Neurosurg 1978;49(3):460-463

15 Nakazawa T, Inoue T, Suzuki F, Nakasu S, Handa J. Solitary intracranial chondroma of the convexity dura: case report. Surg Neurol 1993;40(6):495-498

16 Linsen M, Junmei W, Liwei Z, Jianping D, Xuzhu C. An intracranial chondroma with intratumoral and subarachnoidal hemorrhage. Neurol India 2011;59(2):310-313

17 Maheshwari V, Mehdi G, Varshney M, et al. Intracranial chondroma: a rare entity. BMJ Case Reports 2011;doi:10.1136/ bcr.03.2011.4047

18 van Nielen KM, de Jong BM. A case of Ollier's disease associated with two intracerebral low-grade gliomas. Clin Neurol Neurosurg 1999;101(2):106-110

19 Khosrovi H, Sadrolhefazi A, el-Kadi H, Bloomfield SM, Schochet SS. Intradural convexity chondroma: a case report and review of diagnostic features. W V Med J 2000;96(6):612-616

20 Berkmen YM, Blatt ES. Cranial and intracranial cartilaginous tumours. Clin Radiol 1968;19(3):327-333

21 Matz S, Israeli Y, Shalit MN, Cohen ML. Computed tomography in intracranial supratentorial osteochondroma. J Comput Assist Tomogr 1981;5(1):109-115

22 Lacerte D, Gagné F, Copty M. Intracranial chondroma. Report of two cases and review of the literature. Can J Neurol Sci 1996; 23(2):132-137

23 Ustün MO, Paksoy N, Kilicarslan B. Cystic chondroma arising from the falx cerebri: a case study with review of literature. Clin Neuropathol 1997;16(1):27-29

24 Nakayama M, Nagayama T, Hirano H, Oyoshi T, Kuratsu J. Giant chondroma arising from the dura mater of the convexity. Case report and review of the literature. J Neurosurg 2001;94(2): 331-334

25 De Coene B, Gilliard C, Grandin C, Nisolle JF, Trigaux JP, Lahdou JB. Unusual location of an intracranial chondroma. AJNR Am J Neuroradiol 1997;18(3):573-575

26 Abdelhamid K, Camras LR, Nijensohn EM, Rosseau GL, Cerullo LJ. Intracranial chondroma arising from the cranial vault: $\mathrm{CT}$ and MR appearance. J Comput Assist Tomogr 1996;20(4):556-558

27 Rosenberg AE. Chordoma and related lesions, chondrosarcoma and osteosarcoma. In: McLendon R, Bigner DD, eds. Russel \& Rubinstein's Pathology of Tumors of the Nervous System. 7th ed. London, UK: CRC Press; 2006:765-787

28 Yasargil MG, Krayenbühl HA. Chondromas. In: Krayenbühl HA, ed. Progress in Neurological Surgery. Basel, Switzerland: Karger Publishers; 1975:435-463 